\title{
REMEMBERED/REPLAYED (OR BRITT AND ALEX'S ABANDONED OBJECTS)
}

Karla Kelsey

Through the city I chased the woman with chopsticks in her hair. She promised happiness several years from now-said that in the end he wouldn't care that the Shetland pony was a lie or that there were never any ancestral copper mines.

One foot in the basin of the claw foot sink-the other on the blue velour toilet seat. Balanced.

He glues seashells to the mirror.

We never threw away the dead jade plant. We never waited under the carport. We ignored the plate shards scattered in the rode bed.

Fan shells clatter to green tiled ground.

There were blue-white walls.

On the pier alone she tastes the wooden railing. Splinters piercing tongue.

He creates a plaster cast of an exotic facenames it Bali. In Redondo five dumpsters painted red. 
That season we slept on the roof $a$ la open air. Office buildings lit the sky. He drank grapefruit juice. We built and sold ten wooden candelabras furnished with 25 -cent votive candles.

She leaves behind a sketch of a black stallion in mid-prance. He leaves an audio tape of a car hitting a sound wall. 